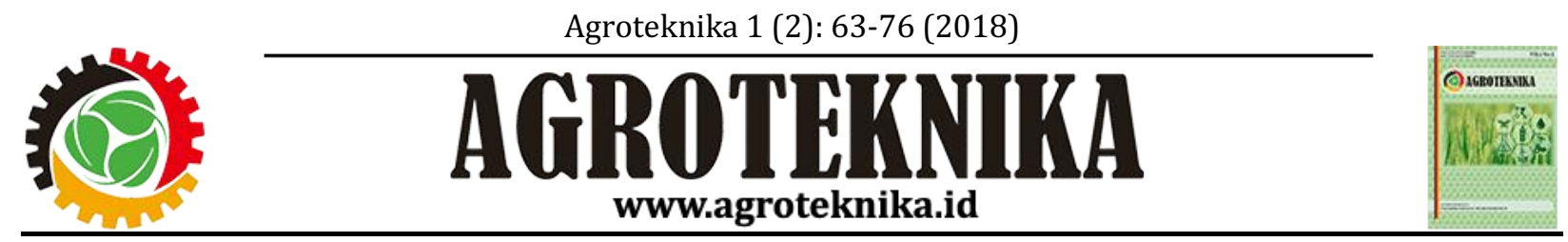

\section{Rancang Bangun Mesin Pengiris Buah Pinang Muda Tipe Horizontal}

\section{Design and Development of Horizontal Type Areca Nut Slicer Machine}

Fauzan Azima, Perdana Putera*, Oktaviyani, Rahmad Zulfani, Rudi Hernando

Program Studi Mesin dan Peralatan Pertanian, Politeknik Pertanian Negeri Payakumbuh

${ }^{*}$ Penulis Korespondensi

Email : perdanaputera81@gmail.com

\begin{abstract}
Abstrak. Biji pinang merupakan salah bahan campuran dalam memakan sirih, bahan campuran pembuatan permen, zat pewarna merah alami, dan diekstrak untuk mendapatkan zat-zat antioksidan alami yang menguntungkan seperti tanin. Pinang muda diolah ditingkat petani dalam bentuk irisan yang kemudian dikeringkan. Penelitian ini bertujuan untuk mempercepat proses produksi dan mengurangi kecelakaan kerja karena pengolahan buah pinang muda biasanya dilakukan dengan cara diiris tipis dengan menggunakan pisau. Prinsip pengirisan pinang ini dilakukan secara horizontal dengan mengubah gerak rotasi dari motor listrik menjadi gerak linear bolak-balik. Dengan adanya mesin ini diharapkan pekerjaan pengirisan akan lebih efektif dan efisien dari segi waktu serta aman bagi pekerja itu sendiri. Perbandingan kinerja mesin pengiris pinang muda dengan alat manual dengan menggunakan mesin pengiris adalah $1: 15,54$. Dari uji analisa ekonomi maka didapat harga jual Rp. 5.070.000, biaya tetap (Fixed cost) Rp 1.277.640,Itahun, biaya tidak tetap (Variable cost) Rp 11.361,56,-/jam, biaya pokok Rp.458.869 dan Break Event Point 20.607,09 kg/tahun.
\end{abstract}

Kata Kunci : pinang, mesin pengiris, vertikal

Abstract. Areca nut is one of the ingredients in eating betel nut, a mixture of making sweets, natural red colouring agents, and extracted to obtain beneficial natural antioxidants such as tannins. On farmer level, areca nut is processed to sliced form before being dried. The objective of the research are to fasten the process production and reduce work accidents because areca nut is usually processed using knife. Principle of the machine is by changing rotational to alternatinglinear movement. By using this machine, it is expected that slicing work will be more effective and efficient in terms of time and safety for the workers themselves. The comparison of the performance of the young areca slicer machine with a manual tool using a slicing machine is 1: 15.54. From the economic analysis test, the selling price of $R p$. 5,070,000, fixed costs (Fixed costs) $R p$ 1,277,640, - lyear, variable costs Rp 11,361.56, - per hour, principal costs Rp. 458,869 and Break Event Points 20,607.09 kg /year.

Keywords: areca nut, slicing machine, vertical

\section{Pendahuluan}

Pinang (Areca catechu) adalah sejenis palma yang tumbuh di daerah Pasifik, Asia dan Afrika bagian timur. Biji segar mengandung kira-kira 50\% lebih banyak alkaloid dibandingkan biji yang telah mengalami perlakuan. Zat lain yang dikandung buah ini antara lain arecaidine, 
arecolidine, guracine (guacine), guvacoline dan beberapa unsur lainnya. Secara tradisional, biji pinang digunakan dalam ramuan untuk mengobati sakit disentri, diare berdarah, dan kudisan. Biji pinang sebagai obat tradisional biasa digunakan untuk mengobati cacingan, penghasil zat pewarna merah dan bahan penyamak (Depkes RI, 2007).

Biji buah pinang mengandung proantosianidin, yaitu suatu tannin terkondensasi yang termasuk dalam golongan flavonoid. Proantosianidin mempunyai efek antibakteri, antivirus, antikarsinogenik, anti-inflamasi, anti-alergi, dan vasodilatasi (Fine, 2000). Selain itu pinang digunakan juga untuk mengatasi bengkak karena retensi cairan (edema), rasa penuh di dada, luka, batuk berdahak, diare, terlambat menstruasi, keputihan, beri-beri, malaria, dan memperkecil pupil mata. Biji dan kulit biji bagian dalam dapat juga digunakan bersama-sama dengan sirih untuk menguatkan gigi goyah. Air rendaman biji pinang muda digunakan untuk obat sakit mata Selain sebagai obat penguat gigi kebanyakan masyarakat juga menggunakan biji pinang muda sebagai obat untuk mengecilkan rahim setelah melahirkan dengan cara memasak buah pinang muda tersebut dan airnya diminum selama seminggu (Kristina \& Syahid, 2007).

Biji pinang diperoleh dari buah pinang yang telah dikupas. Biji pinang diperdagangkan setelah dikeringkan baik dalam keadaan utuh, dibelah, atau diiris tipis. Biji pinang dikenal sebagai salah satu campuran makan sirih. Selain itu, biji pinang dapat dijadikan bahan campuran permen, zat pewarna merah alami, dan diekstrak untuk mendapatkan zat-zat antioksidan alami yang menguntungkan seperti tanin.

Pengecilan ukuran (Size reduction) artinya membagi bagi suatu bahan padat menjadi bagianbagian yang lebih kecil dengan menggunakan gaya mekanis atau menekan. Size reduction merupakan salah satu operasi dalam dunia industri dimana komoditi pertanian dikecilkan ukurannya untuk menghasilkan suatu produk yang memiliki nilai mutu dan nilai tambah yang tinggi.

Tujuan dari pengecilan ukuran adalah untuk memudahkan ekstraksi, untuk pemotongan, untuk meningkatkan daya cerna bagi pakan ternak, untuk memudahkan proses selanjutnya, untuk membuang bagian yang tidak diperlukan, untuk meningkatkan penampilan produk. Cara kerja pengecilan ukuran ada tiga yaitu dengan cara pemotongan (Cutting), cara penghancuran (Crushing), cara pengguntingan (Shearing).

Pengecilan ukuran dengan pemotongan merupakan cara pengecilan ukuran dengan menghantamkan ujung suatu benda tajam pada bahan yang dipotong. Struktur permukaan yang terbentuk oleh proses pemotongan relatif halus, pemotongan lebih cocok dilakukan untuk sayuran dan bahan lain yang berserat (Rifai, 2009). 
Pemotongan atau perajangan biasanya hanya dilakukan pada bahan yang ukurannya agak besar dan tidak lunak seperti akar, rimpang, batang, buah dan lain-lain. Ukuran perajangan tergantung dari bahan yang digunakan dan berpengaruh terhadap kualitas simplisia yang dihasilkan. Perajangan bahan dapat dapat dilakukan secara manual dengan pisau yang tajam dan terbuat dari stainlees ataupun dengan mesin pemotong atau perajang. Bentuk irisan split atau slice tergantung tujuan pemakaian. Perajangan terlalu tipis dapat mengurangi zat aktif yang terkandung dalam bahan. Sedangkan jika terlalu tebal, maka pengurangan kadar air dalam bahan agak sulit dan memerlukan waktu yang lama dalam penjemuran dan kemungkinan besar bahan mudah ditumbuhi oleh jamur (Sembiring, 2007).

Pengecilan ukuran dengan penghancuran (Crushing)

Pengecilan ukuran dengan menggunakan gaya yang melebihi ketahanan bahan sehingga bahan tersebut pecah, cara ini cocok untuk ekstraksi tebu dan pengolahan karet.

\section{Pengecilan ukuran dengan pengguntingan (Shearing)}

Pengecilan ukuran dengan menggunakan kombinasi pemotongan dengan penghancuran (Supardi, 2007).

Pengolahan buah pinang muda melalui pengecilan ukuran (pengirisan) dapat dilakukan secara manual dan mekanis. Pengirisan secara manual menggunakan pisau akan memakan banyak waktu, ketebalan hasil pengirisan tidak seragam, serta berbahaya karena dapat melukai pekerja. Hal inilah yang melatar belakangi penulis untuk merancang dan membuat mesin pengiris buah pinang muda tipe horizontal. Mesin ini dirancang dengan sumber penggerak motor listrik sehingga diharapkan dapat meningkatkan hasil produksi dan membuat pekerjaan pengirisan menjadi lebih efektif dan efisien dari segi waktu serta aman bagi pekerja.

\section{Bahan dan Metode}

\section{Alat dan Bahan}

Alat yang digunakan dalam pembuatan rancangan mesin pengiris buah pinang muda seperti yang terdapat pada Tabel 1.

Tabel 1. Alat yang dibutuhkan

\begin{tabular}{llll}
\hline No. & Jenis Alat & Spesifikasi / Merek & Jumlah \\
\hline 1. & Mesin las listrik & BX6-250 & 2 Unit \\
2. & Mesin gerinda tangan & Makita A24SBF & 2 Unit \\
3. & Mesin gerinda potong & Makita 2414NB & 1 Unit \\
4. & Mesin bor & Bosch Drill GBM 13 RE & 1 Unit \\
5. & Mesin pemotong plat & Makita & 1 Unit \\
6. & Mesin gergaji besi & Dong Jin & 1 Unit \\
7. & Meteran & Essen 15 m & 1 Buah \\
8. & Jangka sorong & Mitutoyo & 1 Unit \\
9. & Mesin gergaji besi & Dong Jin & 1 Unit \\
\hline
\end{tabular}




\begin{tabular}{llll}
\hline 10. & Mesin bubut & Emco Austria 1980 & 1 Unit \\
11. & Kunci-kunci & Tekiro & 1 Set \\
12. & Sikat kawat & Krisbow & 1 Unit \\
13. & Rol siku & Pasekon & 2 Unit \\
\hline
\end{tabular}

Bahan yang digunakan dalam pembuatan mesin pengiris buah pinang dapat dilihat pada Tabel 2.

Tabel 2. Bahan yang dibutuhkan

\begin{tabular}{llll}
\hline No. & \multicolumn{1}{c}{ Bahan } & \multicolumn{1}{c}{ Spesifikasi } & \multicolumn{1}{c}{ Jumlah } \\
\hline 1. & Besi as & Diameter $30 \mathrm{~mm}$ & 1 Batang \\
2. & Besi siku & Tebal $2 \mathrm{~mm} \mathrm{30 \times 30 \times 6}$ & 2 Batang \\
3. & Besi strip & $3 \mathrm{~mm}$ & 3 Meter \\
4. & Pipa & panjang $19 \mathrm{~cm}$ & 3 Unit \\
5. & Elektroda & Rb 2.6 & 1 Kotak \\
6. & Baut & M14,m12 & 10 Buah \\
7. & Pisau pahat & Prohex 16 pcs cutter & 5 Buah \\
8. & Gear & $12,14,15$ & 4 Unit \\
9. & Amplas & Bdx4 inchi & 1 Meter \\
10. & Tiner & 1 liter & 1 Botol \\
11. & Cat semprot & Hitam dan hijau & 1 kaleng \\
12. & Bearing UCP dan UCT & 1 inci & 6 Unit \\
13. & Motor listrik & $1 / 4 H P, 1400 R p m$ & 1 Unit \\
14. & Speed reducer & Ratio $1: 30$ & 1 Unit \\
\hline
\end{tabular}

\section{Metode Pelaksanaan}

Pembuatan mesin pengiris pinang muda diawali dengan pengukuran dan pemotongan bahan yang akan digunakan, berpedoman kepada gambar teknis mesin dan dilanjutkan pemotongan, pengelasan, pembubutan yang dilakukan untuk poros. Proses pembuatan mesin pengiris pinang muda dapat dilihat pada Gambar 1.

\section{Rancangan Mesin Pengiris Pinang Muda Tipe Horizontal}

Rancangan mesin pengiris buah pinang muda ini adalah gambaran secara garis besar mengenai mesin pengiris buah pinang muda yang akan dibuat, mempermudah perhitungan teknik seperti penentuan dimensi komponen dan peletakkan komponen pendukung itu sendiri. Secara fungsional dan struktural, mesin pengiris pinang muda dirancang dengan kriteria sebagai berikut:

\section{Kerangka}

Berfungsi sebagai penyangga atau penopang semua komponen mesin pengiris. Kerangka mesin terbuat dari besi siku yang terdiri dari panjang $150 \mathrm{~cm}$, lebar $50 \mathrm{~cm}$ dan tinggi $50 \mathrm{~cm}$. Rangka mesin pengiris pinang muda dapat dilihat pada Gambar 2. 


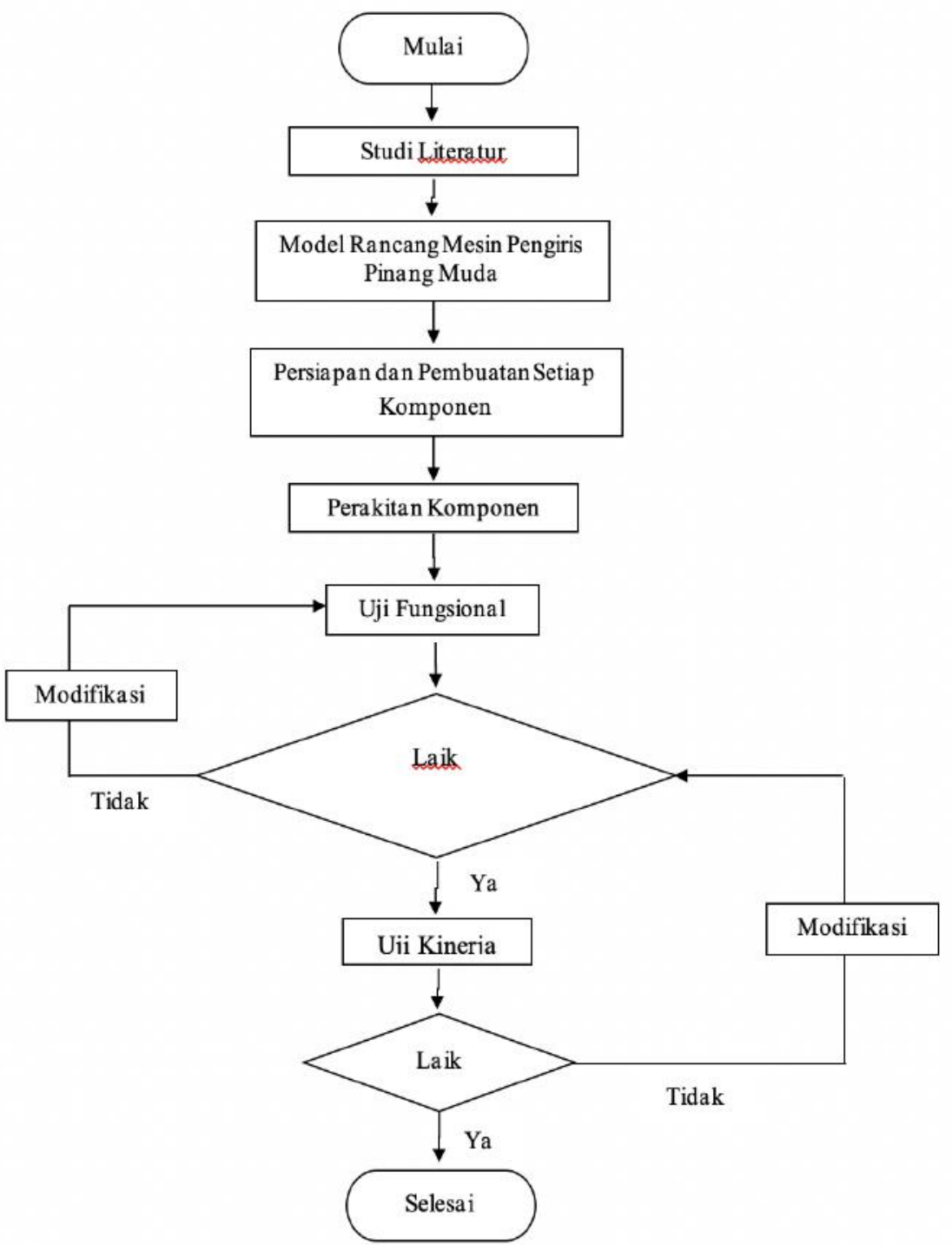

Gambar 1. Diagram alir pembuatan mesin pengiris pinang muda

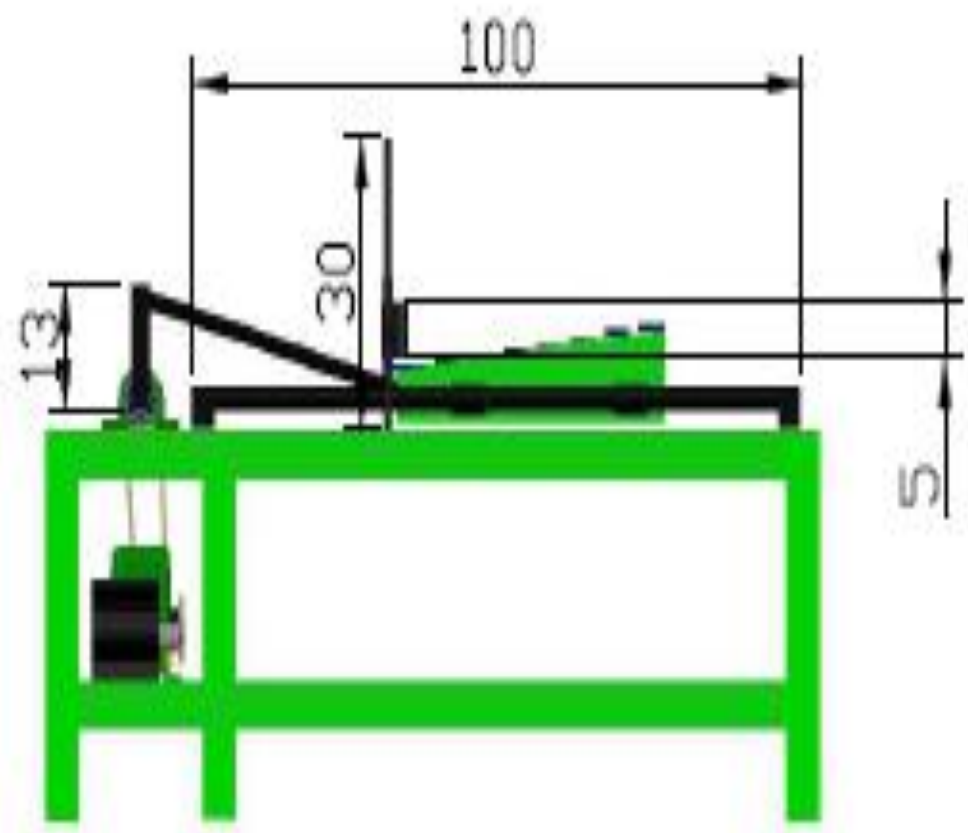

Gambar 2. Kerangka 
Unit penggerak

Berfungsi untuk mengubah energi listrik menjadi energi mekanik. Motor listrik mempunyai daya 3/4 HP dengan kecepatan 1400 RPM. Motor lisrik dapat dilihat pada Gambar 3.

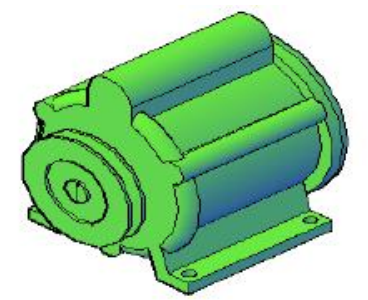

Gambar 3. Motor listrik

Unit transmisi

Berfungsi untuk konversi torsi dan kecepatan yang berbeda - beda untuk diteruskan ke penggerak akhir. Yang termasuk komponen unit transmisi adalah speed reducer, poros, bantalan, bearing, rantai dan sproket. Speed reducer memiliki perbandingan $1: 30$ dengan kode 60. Speed reducer dapat dilihat pada Gambar 4.

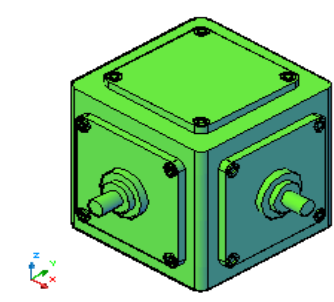

Gambar 4. Speed reducer

Poros terbuat dari besi as dengan diameter besi $30 \mathrm{~mm}$, panjang besi poros $35 \mathrm{~cm}$. Poros dapat dilihat pad Gambar 5.

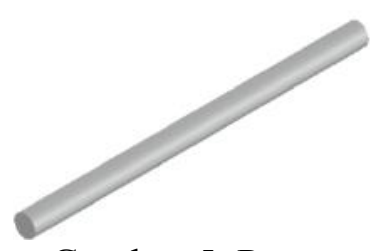

\section{Gambar 5. Poros}

Rantai dan sproket berfungsi meneruskan putaran dari motor listrik ke besi poros. Panjang ukuran chain (rantai) $150 \mathrm{~cm}$ dan sproket yang digunakan 14 tooth pada speed reducer, 15 tooth pada poros. Rantai dan sproket dapat dilihat pada Gambar 6.

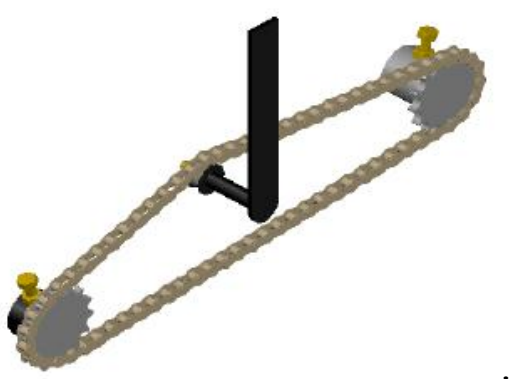

Gambar 6. Rantai dan sproket 
Bearing yang digunakan adalah UCP 205.Berikut ini bentuk dari bearing, dapat dilihat pada Gambar 7.

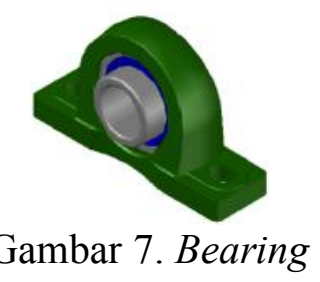

Unit pengiris

Berfungsi untuk mengiris buah pinang muda dengan ketebalan irisan $5 \mathrm{~mm}$ yang digunakan miring terhadap arah putaran yang termasuk unit pengiris yaitu pisau pengiris. Mata pisau terbuat dari besi strip dengan panjang $32 \mathrm{~cm}$. Mata pisau memiliki lebar 4,5 cm, jarak horizontal pisau $0,8 \mathrm{~cm}$ dan jarak vertikal 0,5 cm. Mata pisau dapat dilihat pada Gambar 8 .

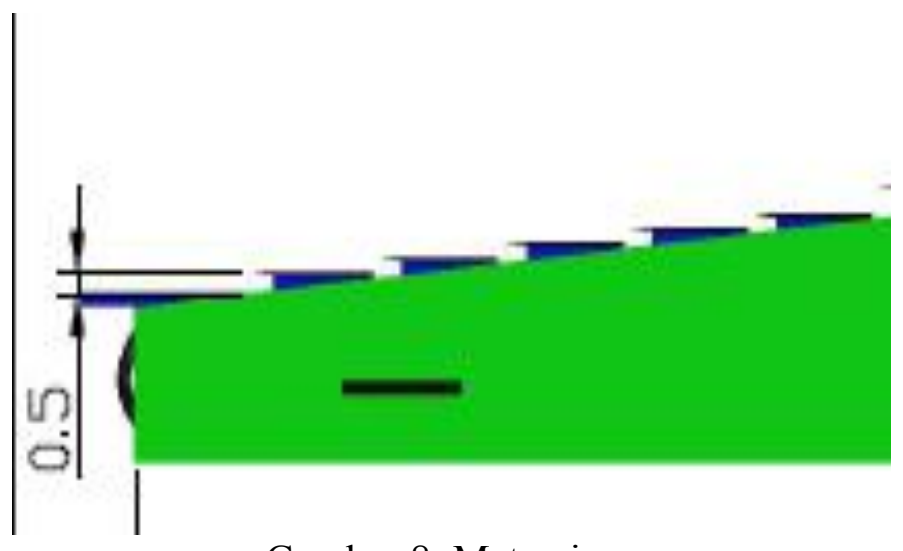

Gambar 8. Mata pisau

Unit pemasukan bahan

Berfungsi sebagai tempat pemasukan buah pinang muda yang akan diiris. Hopper terbuat dari 5 buah pipa besi berukuran tinggi $6 \mathrm{~cm}$, dan diameter pipa 4,2 $\mathrm{cm}$. Hoper atau pemasukan pinang dapat dilihat pada Gambar 9.

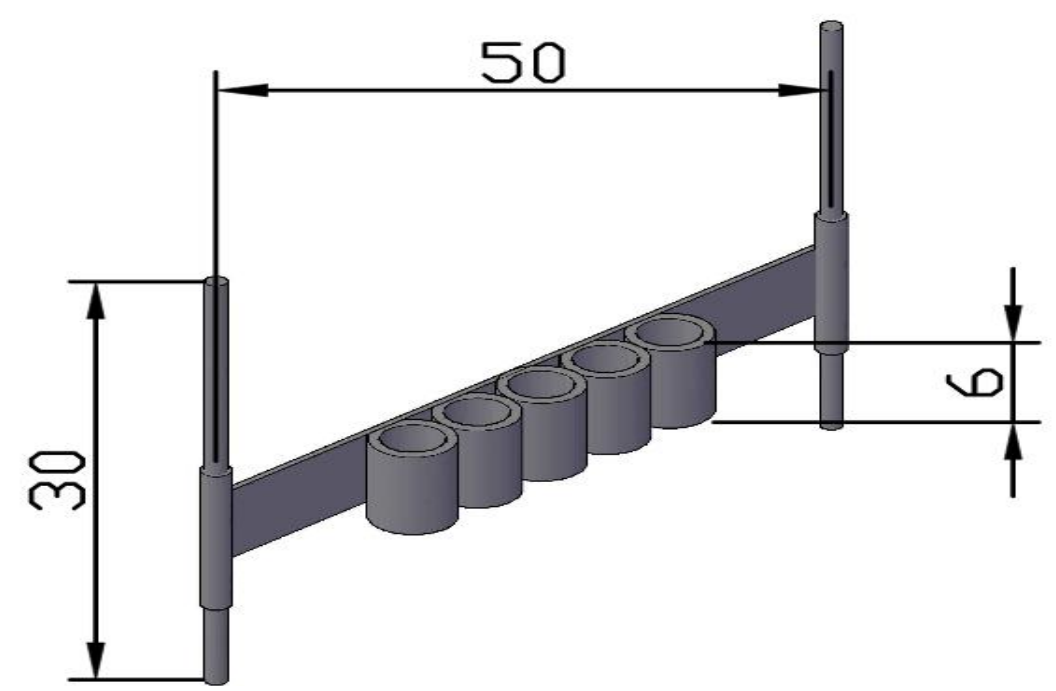

Gambar 9. Hoper atau pemasukan pinang 
Unit perubah gerak putaran

Berfungsi untuk merubah gerakan berputar menjadi gerakan bolak balik seperti roda eksentrik. Roda eksentrik terbuat dari perpaduan besi strip dengan besi as yang berdiameter 1 inchi. Roda eksentrik dapat dilihat pada Gambar 10.

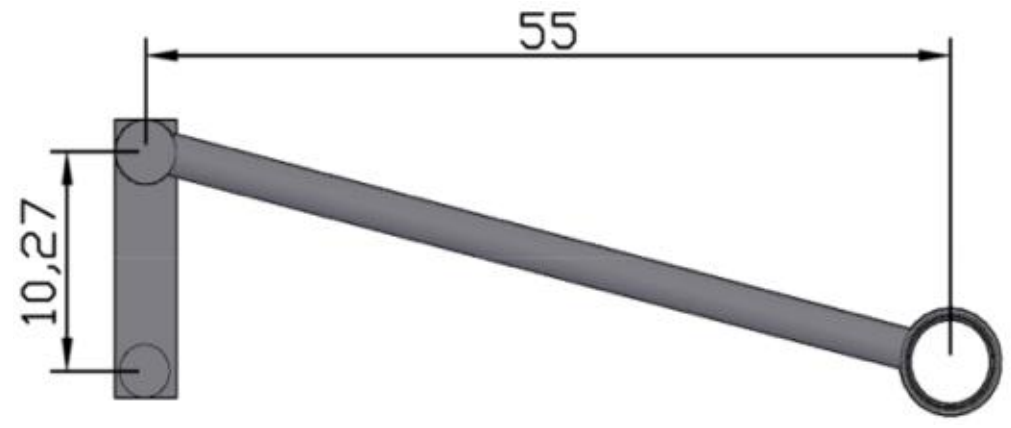

Gambar 10. Roda eksentrik

Disain mesin pengiris pinang muda dibuat dengan menggunakan Autocad 2016 dapat dilihat pada Gambar 10.

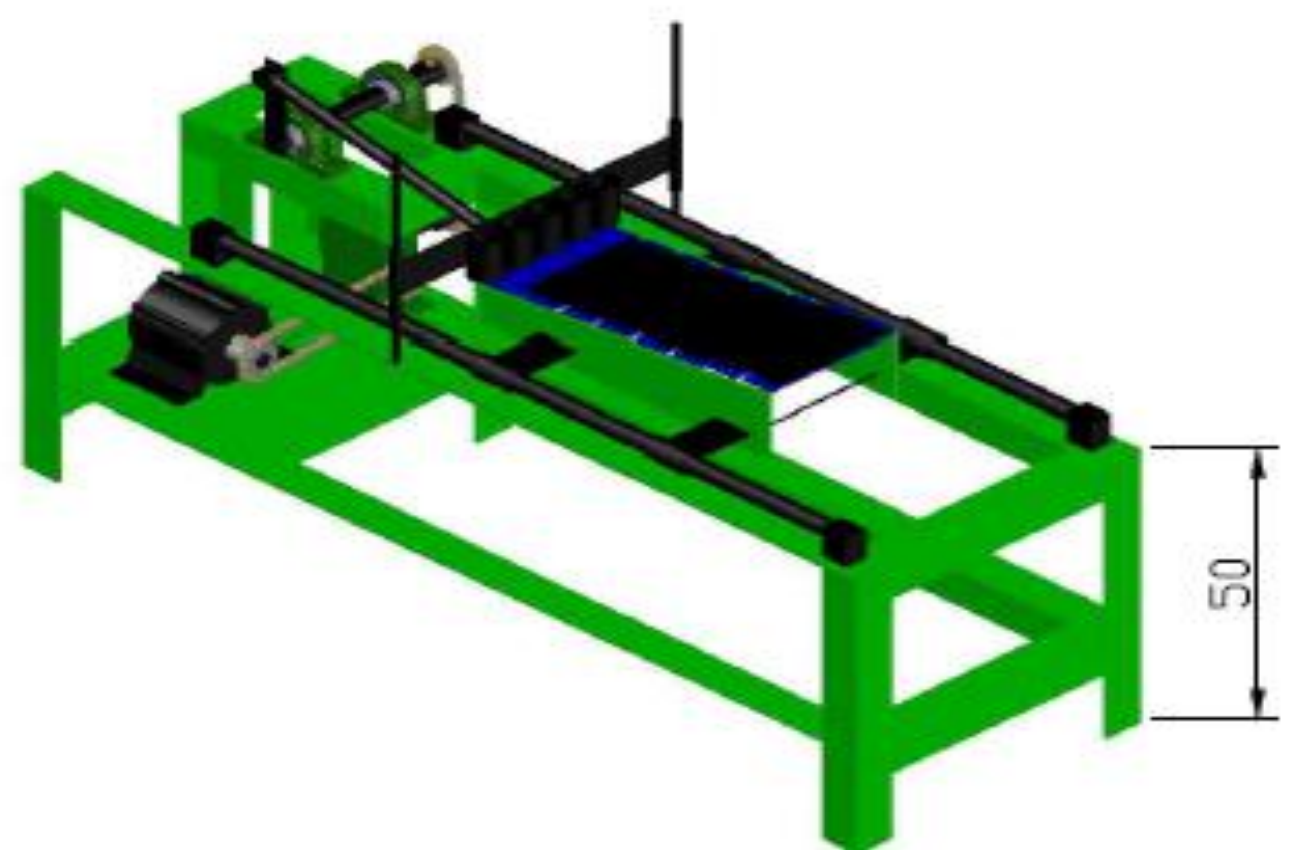

Gambar 13. Disain mesin pengiris pinang

\section{Hasil dan Pembahasan}

Gambar mesin pengiris pinang muda tipe horizontal dan bagian-bagiannya dapat dilihat pada Gambar 11. 


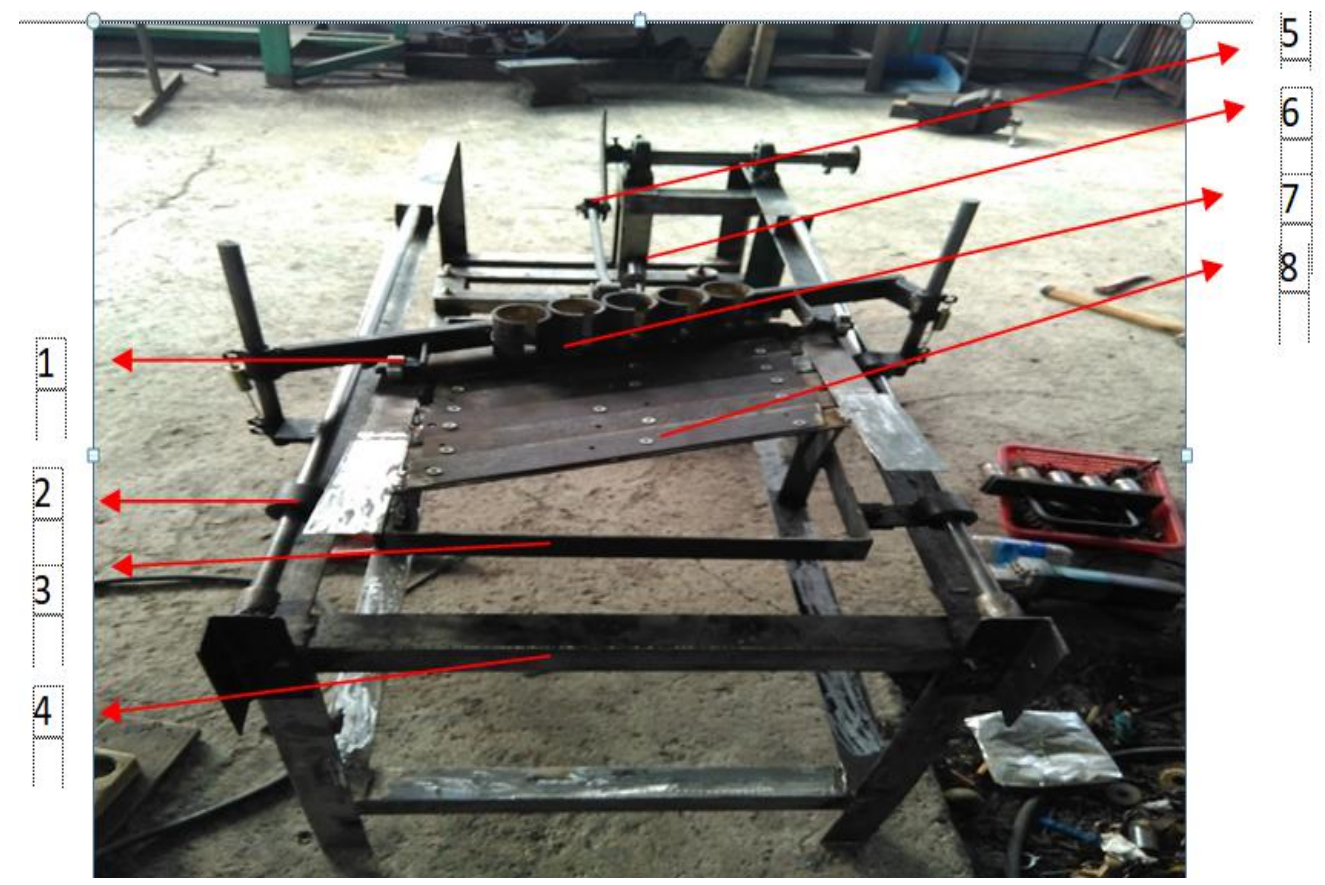

Gambar 11. Mesin pengiris buah pinang muda tipe horizontal

Keterangan:

\section{Bearing}

2. Cincin Rel

3. Kerangka bantalan pisau

4. Kerangka mesin
5. Roda eksentrik

6. Speed reducer

7. Hopper

8. Mata Pisau

Spesifikasi teknis mesin pengiris pinang muda adalah :
a. Panjang $=150 \mathrm{~cm}$
f. Kecepatan
$=43,3 \mathrm{rpm}$
b. Lebar $=50 \mathrm{~cm}$
g. Corong pemasukan $=5$ buah
c. Tinggi $=50 \mathrm{~cm}$
h. Diameter hopper $=4,2 \mathrm{~cm}$
d. Motor listrik $=1400$ RPM
i. Tinggi hopper $\quad=6,5 \mathrm{~cm}$
e. Berat alat $=50 \mathrm{~kg}$
j. Lebar mata pisau $=4,5 \mathrm{~cm}$

Cara kerja mesin pengiris pinang muda tipe horizontal adalah menghidupkan motor listrik sebagai tenaga penggerak mesin pengiris pinang. Setelah mesin di hidupkan, mata pisau akan bergerak secara horizontal karena adanya gaya tarik dari gear dengan bantuan lengan atau roda eksentrik yang bergerak bolak balik dan menggerakan mata pisau mengikuti rel. Tabung pemasukan akan bergerak karena adanya bearing yang menyesuaikan gerakan mata pisau yang mengakibatkan tabung bergerak naik turun mengikuti rel secara vertikal. Pinang dimasukan ke dalam corong pemasukan secara vertikal dan diberi tekanan atau pemberat agar pinang pada saat diiris tidak melompat lompat. Pinang akan diiris secara horizontal oleh mata pisau bertingkat yang 
digerakan oleh motor listrik. Pinang yang telah diiris berukuran $5 \mathrm{~mm}$ sesuai dengan jarak antar mata pisau. Pinang yang telah di iiris jatuh pada wadah penampung yang telah disediakan.

\section{Pengujian Kinerja Alat}

Pengujian kinerja mesin pengiris pinang muda, didapat hasil rata-rata untuk RPM motor listrik 1400 RPM, RPM kerja 43,3 RPM, berat bahan awal $2 \mathrm{~kg}$, berat bahan teriris rata-rata $1,66 \mathrm{~kg}$, kehilangan hasil $0,34 \mathrm{~kg}$, pinang yang baik di dapat $1,1 \mathrm{~kg}$, pinang yang hancur 0,56 $\mathrm{kg}$, ketebalan pengirisan $5 \mathrm{~mm}$, waktu 231,6 detik, dan kapasitas 25,92 kg/jam. Pengujian kinerja mesin pengiris pinang muda dapat dilihat pada Tabel 3.

Tabel 3. Data hasil pengujian mesin pengiris pinang muda

\begin{tabular}{clcccc}
\hline \multirow{2}{*}{ No. } & \multicolumn{1}{c}{ Uraian } & \multicolumn{3}{c}{ Pengujian } & \multirow{2}{*}{ Rata-rata } \\
\cline { 3 - 5 } & & I & II & III & \\
\hline 1. & Berat awal bahan $(\mathrm{kg})$ & 2 & 2 & 2 & 2 \\
2. & Berat bahan teriris (kg) & 1,7 & 1,6 & 1,7 & 1,66 \\
3. & Waktu (detik) & 241,2 & 216 & 237,6 & 231,6 \\
4. & Kehilangan hasil $(\mathrm{kg})$ & 0,3 & 0,4 & 0,3 & 0,34 \\
5. & Pinang yang baik $(\mathrm{kg})$ & 1,1 & 1,0 & 1,2 & 1,1 \\
6. & Pinang yang hancur (kg) & 0,6 & 0,6 & 0,5 & 0,56 \\
7. & Kapasitas kerja (kg/jam) & 25,37 & 26,66 & 25,75 & 25,92 \\
\hline
\end{tabular}

Kapasitas kerja

Kapasitas kerja rata-rata $=\frac{\text { Pengujian ke } 1+\text { pengujian ke } 2+\text { pengujian ke } 3}{3}$

$$
=\frac{25,37 \mathrm{~kg} / \mathrm{jam}+26,66 \mathrm{~kg} / \mathrm{jam}+25,75 \mathrm{~kg} / \mathrm{jam}}{3}=25,92 \mathrm{~kg} / \mathrm{jam}
$$

Laju pengumpanan

Rata-rata laju pengumpanan $(\mathrm{kg} / \mathrm{jam})=\frac{\text { laju ke } 1+\text { laju ke } 2+\text { laju } k e 3}{3}$

$$
=\frac{29,85 \mathrm{~kg} / \mathrm{jam}+33,33^{\mathrm{kg}} / \mathrm{jam}+30,30 \mathrm{~kg} / \mathrm{jam}}{3}=31,16 \mathrm{~kg} / \mathrm{jam}
$$

Persentase kehilangan hasil $(\%)=\frac{\text { kehilangan hasil }(\mathrm{kg}) \times 100 \%}{\text { berat awal bahan }(\mathrm{kg})}$

$$
=\frac{0,33 \mathrm{~kg}}{2 \mathrm{~kg}} \times 100 \%=16,5 \%
$$

Tebal rata-rata $=\frac{\sum_{i=1}^{n} T}{n}$

$$
=\frac{6+4+5+5+5}{5}=5 \mathrm{~mm}
$$

Untuk membandingkan kinerja mesin pengiris pinang muda dengan alat manual yang digunakan masyarakat umum, maka didapat hasil rata-rata pengujian alat pengiris manual sebagai berikut : berat bahan awal $2 \mathrm{~kg}$, berat setalah diiris rata-rata $0,75 \mathrm{~kg}$, waktu yang dibutuhkan 1612 detik, kapasitas alat rata-rata 1,67 kg/jam. Jadi 15,54 kali lebih besar kapasitas mesin pengiris 
pinang muda dibandingkan alat manual pengiris pinang muda. Berikut hasil pengujian alat pengiris pinang muda secara manual dapat dilihat pada Tabel 4.

Tabel 4. Hasil pengujian pengiris pinang muda secara manual.

\begin{tabular}{clcccc}
\hline \multirow{2}{*}{ No. } & \multicolumn{1}{c}{ Uraian } & \multicolumn{3}{c}{ Pengujian } & \multirow{2}{*}{ Rata rata } \\
\cline { 3 - 5 } & & I & II & III & \\
\hline 1. & Berat awal bahan (kg) & 2 & 2 & 2 & 2 \\
2. & Berat bahan teriris (kg) & 0,7 & 0,65 & 0,9 & 0,75 \\
3. & Waktu (detik) & 1476 & 1620 & 1740 & 1612 \\
4. & Kapasitas kerja (kg) & 1,70 & 1,44 & 1,87 & 1,67 \\
\hline
\end{tabular}

1. Kapasitas kerja

Kapasitas rata-rata $=\frac{\text { Pengujian } k e 1+\text { pengujian } k e 2+\text { pengujian } k e 3}{3}$

$$
=\frac{1,70 \mathrm{~kg} / \mathrm{jam}+1,44^{\mathrm{kg}} / \mathrm{jam}+1,87^{\mathrm{kg}} / \mathrm{jam}}{3}=1,67 \mathrm{~kg} / \mathrm{jam}
$$

Mesin pengiris pinang muda ini bekerja dengan baik dan mempunyai kapasitas kerja 25,92 $\mathrm{kg} / \mathrm{jam}$, dengan kapasitas yang tinggi ini bisa mampu meningkatkan hasil produksi para petani khususnya pada pengolahan pinang muda. Mesin pengiris pinang muda ini mempunyai sumber tenaga dari motor listrik 1 phase yang mempunyai daya $0,75 \mathrm{HP}$ dengan kecepatan putaran 1400 RPM sehingga pengguna atau operator merasa nyaman dan aman ketika memakai mesin pengiris pinang muda ini.

Hasil dari pengirisan pinang mempunyai rata-rata ketebalan $5 \mathrm{~mm}$ dan hasil pengirisannya didapat 1,66 kg, kehilangan hasil sebesar $0,34 \mathrm{~kg}$ dari 3 kali pengujian yang mana berat awal bahan $2 \mathrm{~kg}$, dari hasil rata-rata pengirisan itu didapat hasil yang bagus sebesar 1,1 $\mathrm{kg}$ dan yang hancur rata-rata 0,56 dari ketiga pengujian tersebut.

Hasil pengirisan pinang dengan menggunakan mesin pengiris pinang tipe horizontal dapat dilihat pada Gambar 12.
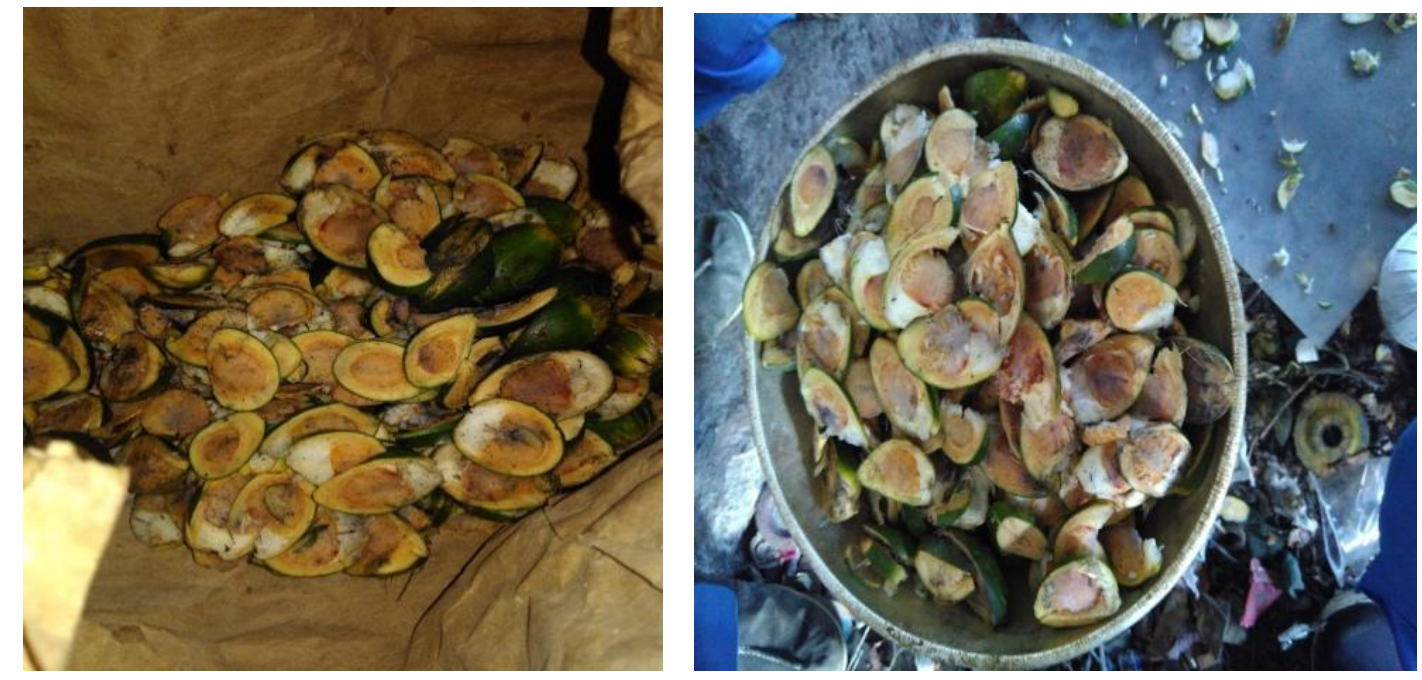

Gambar 12. Hasil pengirisan 


\section{Analisa Ekonomi}

Analisa ekonomi yang serupa telah diterapkan pada penelitian Womsiwor et al, (2018), Irwan et al, (2015), Syafri et al, (2013), Sardino et al, (2018) dan Baskara et al, (2018). Analisa ekonomi tersebut terdiri dari: biaya tetap (fixed cost), biaya tidak tetap (variable cost), Break Event Point (BEP) dan biaya pokok. Dalam analisa biaya operasional mesin pengiris pinang muda ini diasumsikan beberapa hal berikut:

$$
\begin{array}{ll}
\text { Harga jual alat }(\mathrm{P}) & =\mathrm{Rp} 5.070 .000,- \\
\text { Jumlah jam kerja pertahun }(\mathrm{X}) & =2.400 \mathrm{jam} / \mathrm{tahun} \\
\text { Jumlah jam kerja perhari } & =8 \mathrm{jam} \\
\text { Perkiraan umur mesin }(\mathrm{N}) & =5 \text { tahun } \\
\text { Suku bunga pertahun }(\mathrm{I}) & =12 \% / \text { tahun } \\
\text { Upah pengirisan pinang muda per } \mathrm{kg} & =500 / \mathrm{kg} \\
\text { Jumlah operator } & =1 \text { orang } \\
\text { Jumlah hari kerja pertahun } & =300 \mathrm{hari} / \mathrm{tahun}
\end{array}
$$

Biaya Tetap (BT)

Komponen biaya tetap untuk mesin pengiris pinang muda terdiri dari biaya penyusutan dan bunga modal.

Biaya penyusutan

$$
\begin{aligned}
\text { Biaya penyusutan (D) } & =\frac{P-S}{\boldsymbol{N}} \\
& =\frac{R p 5.070 .000-507.000}{5}=912.600,-/ \text { tahun }
\end{aligned}
$$

Bunga modal

$$
\begin{aligned}
\operatorname{Bunga} \text { modal }(\mathrm{I}) & =\frac{i(P) \times(N+1)}{2 N} \\
& =\frac{12 \%(R p 5.070 .000) \times(5+1)}{2 \times 5}=R p 365.040,- \text { tahun }
\end{aligned}
$$

Jadi biaya tetap $(\mathrm{BT})=$ Biaya penyusutan + bunga modal

$$
\begin{aligned}
& =\operatorname{Rp} 912.600,-/ \text { tahun }+\operatorname{Rp~365.040,-/tahun~} \\
& =\operatorname{Rp~1.277.640,-~/tahun~}
\end{aligned}
$$

Biaya tidak tetap (Variabel cost)

Biaya tidak tetap dipengaruhi oleh jam pemakaian alat. Biaya tidak tetap untuk mesin pengiris buah pinang muda terdiri dari upah operator, biaya perawatan dan biaya listrik.

$$
\begin{aligned}
\text { Upah operator } & =\frac{\text { Upah } / \text { hari } \times \text { Jumlah operator }}{\text { Jam kerja } / \text { Hari }} \\
& =\frac{R p 80.000 / \mathrm{Jam} \times 1}{8 \mathrm{jam}}=R p 10.000,-/ \mathrm{jam}
\end{aligned}
$$


Biaya perawatan $=\frac{1,2 \% \times(P-S)}{100 \mathrm{jam}}$

$$
=\frac{1,2 \% \times(R p 5.070 .000-507.000)}{100 \mathrm{jam}}=R p 547,56,-/ \mathrm{jam}
$$

Biaya listrik $=0,55 \mathrm{Kw} \times \mathrm{Rp} 1.480,-/ \mathrm{kwh}=\mathrm{Rp} 814,-$ /jam

Jadi biaya tidak tetap $($ BTT $)=$ Upah operator + biaya perawatan + biaya listrik

$$
\begin{aligned}
& =\operatorname{Rp~10.000,-/jam~}+\operatorname{Rp~547,56/jam+Rp~814,-/~jam~} \\
& =\operatorname{Rp~11.361,56,-/jam~}
\end{aligned}
$$

Biaya Pokok (BP)

Biaya pokok $(\mathrm{BP})=\frac{\frac{B T}{x}+B T T}{C}$

$$
=\frac{\frac{\mathrm{Rp} 1.277 .640,-/ \text { tahun }}{2400 \mathrm{jam}}+\mathrm{Rp} \mathrm{11.361,56,-/ \textrm {jam }}}{25,92 \mathrm{~kg} / \mathrm{jam}}=R p 458,869,-/ \mathrm{kg}
$$

Break Event Point (BEP)

$$
\begin{aligned}
B E P= & \frac{B T}{R-\left(\frac{B T T}{C}\right)} \\
= & \frac{\mathrm{Rp} 1.277 .640,-/ \text { tahun }}{R p 500 / \mathrm{kg}-\left(\frac{\mathrm{Rp} 11.361,56,-/ \mathrm{jam}}{25,92 \mathrm{~kg} / \mathrm{jam}}\right)}=20.607,09 \mathrm{~kg} / \text { tahun }
\end{aligned}
$$

\section{Kesimpulan}

Mesin pengiris pinang muda ini memiliki spesifikasi dengan tinggi $50 \mathrm{~cm}$, lebar $50 \mathrm{~cm}$, panjang $150 \mathrm{~cm}$, lebar mata pisau 4,5 cm, panjang $32 \mathrm{~cm}$ dan jarak antar pisau $8 \mathrm{~mm}$. Pengujian kinerja mesin pengiris pinang muda didapat kapasitas 25,92 Kg/Jam dengan RPM kerja 43,3 RPM dengan waktu rata-rata 3,86 menit, sedangkan yang manual didapat kapasitas 1,67 kg/jam waktu 26,86 menit, sehingga didapat 15,54 kali lipat lebih besar kapasitas mesin dibandingkan manual. Dari uji analisa ekonomi didapat biaya tetap (Fixed cost) Rp 1.277.640,- /tahun, biaya tidak tetap (Variable cost) Rp 11.361,56,-/jam, biaya pokok Rp. 458.869/kg, dan Break Event Point 20.607,09 $\mathrm{kg} / \mathrm{tahun}$.

\section{Daftar Pustaka}

Baskara, I., Putera, P., Sari, I. H., Saputra, A., Ardianto, E. E., Darwisman, R., \& Ardianto, R. (2018). Rancang Bangun Mesin Pengiris Bawang Merah Tipe Vertikal. Agroteknika, 1(1), 39-50. https://doi.org/10.32530/agtk.v1i1.21

Fine, A.M. (2000). Oligomeric Proanthocyanidin Complexes, History, Structure, and Phytopharmaceutical Applications. Altern Med Rev. 5 (2) : 14-15.

Irwan, A., Syafri, E., Evawati, E., \& Putera, P. (2015). Pembuatan dan Uji Kinerja Mesin Pengaduk Adonan Gelamai untuk Peningkatan Produksi Gelamai. Jurnal Teknologi Pertanian Andalas, 19(1), 46-50.

Kristina \& Syahid. (2007). Tanaman Pinang Sebagai Tanaman Obat. Tersedia di http://Artikel Kesehatan Masyarakat.com/2010. Diakses 16 juli 2016. 
Menteri Kesehatan RI. (2007). Kebijakan obat Tradisional Nasional Tahun 2007. Jakarta: Depkes RI.

Rifai, H. (2009). Pengecilan Ukuran. Tersedia (online) http://wwwloanocoid.com/2009. Diakses 30 Juli 2016.

Sardino, S., Ilham, H., Saputra, A., Syahta, R., Herdian, F., \& Jamaluddin, J. (2018). Rancang Bangun Alat Panjat Kelapa Portable. Journal of Applied Agricultural Science and Technology, 2(2), 72-82. https://doi.org/10.32530/jaast.v2i2.47

Sembiring, B. (2007). Teknologi Penyiapan Simplisia Terstandar Tanaman Obat. Warta Puslitbangbun. 13 (2), Agustus 2007.

Supardi, N.I. (2007). Pengecilan Ukuran Produk Pertanian. Yogyakarta : Andi Offset.

Syafri, E., \& Novita, S. A. (2013). Rancang Bangun dan Uji Kinerja Alat Pembuat Asap Cair. Jurnal Teknologi Pertanian Andalas, 17(1), 42-49.

Womsiwor, O., Nurmaini, N., Zikri, A., Hendra, H., Amrizal, A., Yudistira, Y., \& Batubara, F. (2018). Rancang Bangun Mesin Pengupas Dan Pencuci Singkong Tipe Horizontal. Journal of Applied Agricultural Science and Technology, 2(2), 11-19. https://doi.org/10.32530/jaast.v2i2.40 